\title{
Digital Content Category
}

National Cancer Institute

\section{Source}

National Cancer Institute. Digital Content Category. NCI Thesaurus. Code C115468.

A collection of digital content. 